\title{
MERGER DAN AKUISISI: SEBUAH PERKAWINAN PARADOKSAL
}

\author{
Achmad Sobirin*)
}

\begin{abstract}
From human and cultural perspectives, it can be said that merger and aquisition (M\&A) is a kind of paradoxal marriage. While its main objective is to create synergy, the reality shows it differently. Many companies that decided to enter into M\&A fail to achieve its objective particularly due to human and cultural problems. Therefore, to prevent, or at least, to minimize these problems, the companies should prepare psichologically, understand each others, and conduct due dilligent including human and cultural audit before entering into the marriage. This is what this paper is trying to discuss. By discussing this topic it is expected that human and cultural variables being neglected so far, are to be considered into the M\&A's decision so that the implementation of the marriage can be run smoothly.
\end{abstract}

Keywords : merger \& acquisition ( $M \& A)$, paradoxal marriage, open marriage, traditional marriage, modern marriage

\section{PENDAHULUAN}

Merger dan Akuisisi (M\&A) merupakan fenomena bisnis paradoksal. Di satu sisi, intensitasnya terus meningkat tetapi di sisi lain tingkat kegagalannya juga cukup tinggi. Sebagai gambaran, Schweiger, Csiszar and Napier (1993) mengemukakan bahwa sejak tahun 1983 penggabungan usaha yang terjadi di Amerika, setiap tahunnya mencapai angka 2500 lebih. Angka ini belum termasuk keterlibatan perusahaan Amerika dalam M\&A antar negara yang jumlahnya juga meningkat drastis.

Selain Amerika, trend yang sama juga terjadi di Eropa, Asia dan wilayah negara lain. Di Cina misalnya antara tahun 1985-1996 terjadi M\&A dengan total nilai US \$ 5,3 milyar (Milman, 1999). Sedangkan di Indonesia, meski tidak ada angka pasti dan kegiatannya pun tidak setinggi negara-negara maju, tidak luput dari boom M\&A. Pertengahan tahun 1980an sampai awal tahun 1990an merupakan masa-masa subur bagi kegiatan merger dan akuisisi di Indonesia. Secara keseluruhan, seperti dikatakan Cartwright and Cooper (1993a, 1993b, 1993c; 1995), Legare (1998), dan Marks and Mirvis (1997, 1998), M\&A yang terjadi pada tahun 1980-an dan periode sesudahnya meningkat hampir dua kali lipat dibandingkan dengan boom M\&A tahun 1960-an.

Di sisi lain tingkat kegagalan M\&A juga relatif tinggi berkisar antara 50\% sampai 70\% (Cartwight and Cooper 1993c). Termasuk dalam kategori kegagalan M\&A misalnya: penggabungan usaha tersebut tidak mencapai tujuan finansial yang dikehendaki (Chatterjee, et al.1992), tidak meningkatkan harga saham di pasar bursa (Schweiger, Csizar, Napier, 1993), tidak menciptakan sinergi yang biasa disebut "2+2 = 5 effect" (Mirvis and Marks, 1992), dan ujung-

*) Dosen dan Pembantu Dekan I Fakultas Ekonomi Universitas Islam Indonesia, Yogyakarta 
ujungnya terjadi perceraian kembali tidak lama setelah penggabungan usaha tersebut berlangsung (Cartwight and Cooper 1993a,b,c).

Karena secara historis M\&A adalah domain para ekonom dan para strategist (Cartwright and Cooper, 1993c) maka kegagalan M\&A biasanya hanya dikaitkan dengan faktor-faktor berikut: (1) jeleknya pengambilan keputusan karena membeli perusahaan lain dengan harga yang terlalu tinggi, (2) terjadi kesalahan dalam mengelola keuangan sehingga realisasi bertambahnya skala ekonomi dan rasio-rasio laba yang diharapkan tidak tercapai, dan (3) terjadi perubahan pasar yang mendadak.

Memang tidak dipungkiri bahwa ketiga faktor di atas bisa menghambat keberhasilan M\&A, namun harus diakui pula bahwa sesungguhnya M\&A bukan sekedar plain buying - sekedar mengambil alih aset perusahaan lain (Salgo, 1968) me-lainkan menggabungkan dua kelompok manusia yang berbeda sikap dan prilaku, dan menggabungkan dua budaya yang berbeda (Nahavandi and Malekzadeh, 1988), sehingga keberhasilan atau kegagalan M\&A juga sangat bergantung pada kedua faktor ini. Davy et al. $(1988,1989)$ bahkan menyatakan bahwa 33\% sampai 50\% kegagalan M\&A karena faktor manusia dan budaya. Sayangnya kedua faktor ini masih sering diabaikan dalam pengambilan keputusan M\&A (Schweiger and Ivancevich, 1985). Akibatnya tidak hanya tujuannya tidak tercapai, M\&A sering menjadi bumerang yakni menjadi bencana bagi perusahaan tersebut (Feldman, 1995).

Uraian di atas menunjukkan bahwa faktor manusia dan budaya menjadi salah satu determinan keberhasilan dan atau kegagalan M\&A. Jika demikian, sebelum memutuskan penggabungan usaha, selayaknya para pengambil keputusan terlebih dahulu memahami kedua faktor ini lebih baik dan melakukan persiapan-persiapan psikologis layaknya seseorang akan melakukan sebuah perkawinan (Cartwright and Cooper, 1993b). Dengan pemahaman ini diharapkan agar saat implementasi M\&A, persoalan-persoalan manusia dan budaya bisa diantisipasi lebih dini dan bisa diminimalisir. Seperti dikatakan Schweiger, Csiszar and Napier (1993), kunci keberhasilan M\&A selain karena pemilihan strategi yang tepat dan harga pembelian yang wajar juga bergantung pada efektifitas implementasinya yang tidak lain adalah bagaimana mengelola manusia dan budaya, baik sebelum maupun sesudah M\&A sah secara hukum.

Tulisan ini dimaksudkan untuk menguraikan M\&A dari aspek manusia dan budaya (dari soft issues dalam bahasa Cartwright and Cooper, 1995) yakni melihat kemungkinan timbulnya masalah M\&A oleh kedua aspek ini dan upayaupaya preventif yang perlu dilakukan untuk meminimalisir masalah tersebut agar dalam implementasinya, M\&A berjalan sesuai dengan yang diharapkan yakni menciptakan sinergi.

\section{M\&A SEBAGAI SEBUAH PERKAWINAN}

Membuat perumpamaan (metafora) M\&A layaknya sebuah perkawinan bukanlah hal baru dalam literatur M\&A (lihat misalnya Ivancevich, Schweiger and Power, 1987). Layaknya sebuah perkawinan, memahami sifat/karakter masingmasing pihak sebelum perkawinan tersebut dilaksanakan merupakan tindakan 
yang bijak mengingat perkawinan bukan sekedar bertemunya dua insan dalam pelaminan melainkan pertemuan dua sifat, karakter, kebiasaan dan budaya yang berbeda. Oleh karenanya kedua belah pihak kadang-kadang perlu melakukan perubahan dan harmonisasi sifat, kebiasaan dan budaya agar perkawinan tersebut bisa berlangsung lama dan mencapai tujuannya.

Sayangnya, sifat, kebiasaan dan budaya dari masing-masing pihak tidak mudah berubah bahkan cenderung dipertahankan meski perkawinan tersebut telah berlangsung. Kecenderungan ini muncul tidak lain karena dalam diri manusia sudah terbentuk mind-set (Maks and Mirvis, 1998) atau mental programming dalam bahasa Hofstede (1997). Harapan bagi kita adalah sesulit apapun perubahan itu bukan berarti bahwa mind-set tidak bisa dirubah (Hofstede, 1997). Tetapi harus disadari pula bahwa perubahan tersebut bukan pekerjaan mudah dan memerlukan waktu yang lama (Kotter and Heskett, 1992: 105). Oleh karena itu jika perubahan mind-set merupakan suatu keharusan (demi langgeng dan tercapainya cita-cita perkawinan) maka kerja sama dari pihak-pihak yang terlibat dalam perkawinan tampaknya tidak dapat dihindarkan.

Tidak berbeda dengan sebuah perkawinan, M\&A juga akan mengalami hal serupa. M\&A selalu berhadapan dengan perbedaan yang (kadang-kadang) memerlukan perubahan dan penyesuaian demi suksesnya penggabungan usaha tersebut. Sayangnya dalam melakukan M\&A kedua belah pihak cenderung mempertahankan mind-set masing-masing yakni mind-set perusahaan pembeli dan mind-set perusahaan penjual meski penggabungan usaha telah berlangsung (Marks and Mivis, 1998). Itulah sebabnya saat M\&A dimplementasikan sering terjadi benturan kepentingan antara perusahaan yang mengakuisisi (berinisiatif melakukan merger) dengan perusahaan yang dibeli/dimerger.

\section{Mind-set Perusahaan Pembeli}

Perusahaan pembeli atau dalam kontek merger perusahaan yang memimpin perusahaan lain cenderung merasa menang dan superior (superiority syndrome). Bagi para eksekutif perusahaan tersebut, kemenangan ini juga menunjukkan seolah-olah mereka mempunyai kemampuan untuk memimpin perusahaan lain dan secara psikologis memperoleh kepuasan dalam bekerja karena merasa telah menyelesaikan pekerjaan besar. Suasana ini membuat mereka merasa lebih percaya diri, ingin cepat-cepat menyelesaikan persoalanpersoalan M\&A yang masih mengambang, dan merasa mempunyai bargaining posistion yang lebih kuat ketimbang para eksekutif dari perusahaan yang dimerger atau diakuisisi.

Sikap semacam ini bisa berdampak pada suatu anggapan bahwa ketajaman bisnis mereka - baik dalam hal strategi, kebijakan, prosedur, sistem, teknologi maupun orang-orangnya, lebih superior ketimbang perusahaan yang dimerger/ diakuisisi dan di sisi lain menganggap pihak lain lebih inferior. Pernyataan seperti: "mereka masih bekerja keras untuk menyelesaikan persoalan yang kami telah selesaikan lima tahun lalu", atau "sistem kita akan membawa mereka ke dunia bisnis modern" atau "teknologi yang kita miliki akan membwa mereka ke perusahaan kelas dunia" menjadi hal yang biasa. 
Karena perasaan superioritas itu pula, saat implementasi M\&A mulai dijalankan, perusahaan yang memimpin mulai bergerak cepat dan mulai melakukan konsolidasi untuk meraih keuntungan yang sudah dibayangkan sebelumnya. Dalam kondisi yang serba cepat ini, perusahaan yang memimpin mulai mendominasi pihak lain. Janji-janji yang diberikan saat negosiasi berlangsung seperti misalnya mereka akan menghormati tradisi dan kebiasaan-kebiasaan perusahaan yang dimerger/diakuisisi, mereka lupakan begitu saja. Dibenak mereka, yang penting bagaimana anggaran dan target-target perusahaan bisa tercapai dan kegiatan perusahaan menampakkan hasilnya, bukan bagaimana menyelesaikan M\&A secara fair atau tidak mengakibatkan gejolak.

\section{Mind-set Perusahaan yang Dibeli}

Jika para eksekutif perusahaan yang meng-akuisisi mempunyai perasaan menang dan bersikap merendahkan pihak lain, para eksekutif dari perusahaan yang dimerger/diakuisisi mempunyai sikap dan perasaan yang sebaliknya. Mereka cenderung manganggap pihak lain sebagai barbar dan tidak punya perasaan. Bahkan dalam konteks M\&A yang bersifat friendly sekalipun, perasaan-perasaan seperti ini tidak bisa dihilangkan begitu saja. Akibatnya para eksekutif mengalami cultural shock (Hofstede, 1997) segera setelah M\&A diumumkan. Mereka merasa tidak siap menghadapi tugas-tugas dan tanggung jawab baru, tidak siap dengan perubahan struktur organisasi yang baru, bahkan mereka terus bersikap waspada terhadap manajer yang baru.

Implikasi dari perasaan takut, bingung dan curiga yang dialami para eksekutif menjadikan mereka berupaya untuk mengatasi/mengendalikan dirinya. Diantara-nya dengan melakukan tindakan-tindakan defensif seperti melakukan regrouping (memisahkan diri dari kelompok eksekutif/karyawan perusahaan pembeli) sebagai langkah awal untuk menyusun serangan balik terhadap musuhnya (perusahaan pembeli). Tidak patuh, sabotase, atau serangan secara agresif merupakan bentuk-bentuk serangan balik yang biasa dilakukan para eksekutif perusahaan penjual. Tujuannya mereka ingin merebut kembali (buyback) perusahaan yang diakuisisi atau dimerger (Mivis and Sales, 1990).

Mulanya memang para eksekutif hanya marah kepada pimpinan mereka, sebab karena merekalah (para pimpinan perusahaan yang memutuskan M\&A) para eksekutif menjadi bingung, curiga dan takut. Perasaan marah ini kemudian bergeser bukan lagi ke pimpinan mereka tetapi ke pimpinan perusahaan yang mengakuisisi. Perasaan seperti ini biasanya berlangsung cukup lama. Jika mereka secara psikologis dapat mengatasi perasaannya, maka langkah berikutnya mencoba melakukan bargaining dengan pimpinan yang baru sampai kepentingankepentingan mereka terakomodasi. Dilihat dari segi waktu, kondisi ini bisa berlangsung lama, biasanya dalam ukuran tahun, bahkan ada diantara mereka yang tidak pernah bisa menghilangkan perasaan-perasaan tersebut di atas sehingga pilihan yang mereka tempuh adalah keluar dari perusahaan.

Marks and Mirvis (1998) lebih lanjut mengatakan bahwa perbedaan mind-set tersebut tidak mungkin bisa dihilangkan sama sekali. Menghilangkan perbedaan mind-set merupakan pekerjaan sia-sia dan hanya bersifat artifisial. 
Yang penting adalah menyadarkan mereka bahwa kesepakatan sudah dibuat dan M\&A sudah sah secara hukum. Artinya, agar persoalan-persoalan manusia dan budaya bisa diminimalisir, selain perbedaan tersebut harus diintegrasikan (Pablo, 1994), para pengambilan keputusan juga patut memperhatikan dimensi psikologis perkawinan dalam M\&A dan jenis-jenis perkawinannya itu sendiri (Cartwright and Cooper, 1993b).

\section{Dimensi Psikologis Perkawinan dalam M\&A}

Cartwright and Cooper (1993b) mengidentifikasikan dimensi-dimensi psikologis dalam M\&A yang perlu dipahami ketika dua perusahaan melangsungkan sebuah perkawinan, diantaranya:

1. M\&A, layaknya sebuah perkawinan, merupakan aktivitas yang mahal. Untuk menggabungkan dua usaha, disamping harus membayar perusahaan yang diambil alih, juga harus mengeluarkan biaya-biaya lain seperti jasa konsultan, jasa perantara, biaya iklan dan biaya-biaya lain yang terkait yang jumlahnya tidak sedikit. Demikian juga jika terpaksa perkawinan ini tidak bisa berlangsung lama, untuk berpisah juga memerlukan biaya yang tidak sedikit. Melihat kenyataan bahwa tingkat perceraian M\&A begitu tinggi - lebih dari $50 \%$ maka perceraian tersebut identik dengan penghamburan uang yang sia-sia. Secara finansial, kegagalan ini akan tampak lebih buruk lagi karena biasanya diikuti dengan memburuknya citra perusahaan dan anjoknya harga saham di pasar bursa. Belum lagi biaya sosialnya: seperti keluarnya para expertise dari perusahaan.

2. Perkawinan yang berhasil dan berumur panjang hanya akan terjadi jika kedua belah pihak melakukan persiapan-persiapan yang lebih baik, lebih lama dan keduanya memahami mind-set dan karakter masing-masing, bukan sekedar mengacu pada keuntungan strategis dari perkawinan tersebut. Dalam hal ini penilaian terhadap kompatibilitas budaya kedua belah pihak khususnya setelah keduanya bergabung, menjadi sangat penting karena sekali lagi M\&A bukan sekedar plain buying melainkan penggabungan dua budaya.

3. Keberhasilan sebuah perkawinan tidak semata-mata bergantung pada bagaimana strategi penggabungan diterapkan tetapi lebih bergantung pada bagaimana implementasinya. Hal ini berarti keterlibatan para eksekutif menengah dan manajer lini dalam negosiasi M\&A sangat dianjurkan mengingat merekalah yang nantinya terlibat dalam operasionalisasi M\&A. Di Jepang misalnya, praktek semacam ini (melibatkan para eksekutif menengah dalam negosiasi) merupakan hal yang biasa sehingga para eksekutif menegah dan manajer lini tidak mengalami stress setinggi rekan-rekan mereka yang ada di Amerika atau negara-negara barat lainnya ketika menghadapi M\&A. Sebab, karena keterlibatannya dalam proses negosiasi M\&A, para eksekutif menengah ini sudah bisa memprediksi apa yang kira-kira terjadi setelah kedua perusahaan bergabung.

4. Pengalaman-pengalaman sebelumnya bukan prediktor keberhasilan sebuah perkawinan dimasa datang. Artinya, bagi perusahaan yang pernah melakukan M\&A, pengalaman tersebut dan cara-cara yang digunakan tidak 
bisa begitu saja diterapkan pada M\&A berikutnya mengingat adanya perbedaan lingkungan dan karakteristik perusahaan yang akan digabung. Sebagai contoh, menggabungkan dua perusahaan sejenis (horizontal $M \& A)$ tentunya memerlukan pola dan cara penggabungan yang berbeda dengan penggabungan dua perusahaan lain jenis (vertical $M \& A$ ).

5. Perkawinan yang berhasil terjadi antara dua pihak yang saling mengakui dan menerima isi kontrak. Kesepakatan M\&A yang cenderung bersifat implisit ketimbang eksplisit sering menimbulkan kesalah pahaman dari kedua belah pihak. Oleh karenanya kalau masing-masing pihak tidak memahami dan mangakui mind-set partnernya, diperkirakan kegagalan $M \& A$ akan semakin tinggi.

\section{Jenis-jenis Perkawinan Dalam M\&A}

Dilihat dari aspek prilaku dan budaya, secara umum ada tiga jenis perkawinan dalam M\&A yaitu: perkawinan terbuka, perkawinan tradisional, dan perkawinan modern atau kolaboratif (Cartwright and Cooper, 1993b; Napier, 1989).

Perkawinan Terbuka. Yang dimaksud dengan perkawinan terbuka adalah penggabungan dua perusahaan di mana masing-masing perusahaan mau saling menerima apa adanya kondisi pihak lain. Disamping itu, kedua belah pihak juga berupaya mempertahankan independensi masing-masing. Dalam hal ini, ha-hal yang bersifat khas bagi sebuah organisasi (idiosyncrasy), perbedaan prilaku dan perbedaan budaya organisasi dianggap bukan merupakan variabel penting yang perlu diperdebatkan. Artinya, masing-masing pihak tidak berupaya merubah prilaku atau budaya organisasi pihak lain sebab kedua variabel tersebut tidak dianggap sebagai faktor pengganggu karena perbedaan tersebut bersifat natural.

Perkawinan Tradisional. Perkawinan tradisional adalah penggabungan dua perusahaan di mana salah satu pihak merasa lebih dominan ketimbang pihak lain. Perkawinan seperti ini biasa disebut sebagai perkawinan yang tidak setara (unequal marriage). Karena adanya ketidak setaraan tersebut maka pihak yang merasa lebih dominan menganggap bahwa dirinya lebih berhak menentukan arah dan masa depan perusahaan baru baik dalam hal misi dan visi perusahaan maupun tujuan, strategi, budaya dan prilaku organisasinya. Oleh sebab itu jika saat negosiasi M\&A berlangsung, misalnya diketahui ada perbedaan dalam gaya kepemimpinan dan budaya organisasi, maka segera setelah M\&A disetujui dan sah secara hukum, pihak yang merasa dominan tersebut cenderung memaksa perusahaan yang dimerger/diakuisisi mengikuti tata nilai dan keyakinannya serta semua peraturan yang berlaku di perusahaan yang dominan tersebut. Akuisisi Apollo Computer oleh Hewlett Packard (Legare, 1998) adalah salah satu contoh bentuk perkawinan tradisional. Dalam contoh ini, HP merasa lebih dominan ketimbang Apollo oleh karenanya inisiatifinisiatif perubahan dilakukan oleh HP, dan konsekuensinya, apa yang dimaui HP harus dituruti Apollo Computer. 
Perkawinan Modern atau biasa disebut sebagai perkawinan kolaboratif. Disebut demikian karena pada dasarnya pihak-pihak yang bergabung, secara konsisten berupaya untuk mencapai tujuan M\&A yang sesungguhnya yakni mencapai sinergi yang biasa dianalogikan dengan "2+2 = 5 effect". Dalam bahasa behavioral, kolaborasi terjadi karena salah satu pihak berupaya maksimal untuk mencapai tujuannya dan di sisi lain ia juga ingin membantu pihak lain secara maksimal mencapai tujuannya (lihat misalnya George and Jones, 1999, p. 663). Jadi dalam perkawinan modern ini masing-masing pihak menyadari bahwa mereka mempunyai beberapa keunggulan dan sekaligus kelemahan dibanding pihak lain. Mereka juga sadar bahwa kelemahan tersebut hanya bisa di atasi jika mereka bergabung atau memiliki perusahaan lain. Itulah sebabnya kedua belah pihak berusaha untuk share learning - saling belajar dari pihak lain. Proses pembelajaran ini didasari oleh suatu asumsi dan kesadaran bahwa penggabungan dua perusahaan akan memberi nilai tambah ketimbang jika mereka harus beroperasi sendiri-sendiri. Perbedaan prilaku dan budaya perusahaan dengan demikian tidak dianggap sebagai faktor penggangu. Kalau toh ada tanda-tanda bahwa budaya menjadi faktor pengganggu maka perbedaan budaya tersebut akan dikelola dan diintegrasikan kedalam perusahaan baru sehingga tercipta budaya baru yang terbaik bagi keduanya.

Dari ketiga jenis perkawinan ini, jenis pertama - perkawinan terbuka banyak ditemui pada penggabungan usaha yang kegiatan usahanya tidak sejenis. Secara natural perusahaan yang kegiatan usahanya berbeda mempunyai karakter dan budaya yang berbeda pula (Schneider and Barsoux, 1997) sehingga ketika kedua perusahaan tersebut bergabung, persoalan manusia dan budaya bukan merupakan persoalan mendasar. Itulah sebabnya M\&A yang terjadi tahun 1960-an di mana kecenderungannya saat itu adalah mengembangkan business portfolio atau konglomerasi ketimbang horizontal M\&A seperti yang terjadi setelah tahun 1980an, persoalan-persoalan M\&A yang berkaitan dengan aspek manusia dan budaya tidak begitu menonjol dan tidak menjadi perhatian utama para pengambil keputusan saat itu.

Meski demikian bukan berarti bahwa M\&A perusahaan tidak sejenis sama sekali tidak menghadapi masalah manusia dan budaya. M\&A lintas negara misalnya, sekalipun terjadi antar perusahaan tidak sejenis kemungkinan akan menghadapi persoalan manusia dan budaya. Persoalan ini muncul karena masing-masing negara mempunyai sistem nilai dan budaya nasional yang berbeda (Hofstede, 1980). Perbedaan ini menjadi faktor utama perbedaan perilaku dan budaya organisasi bagi perusahaan yang berlokasi di negara yang berbeda. Akibatnya, jika dua perusahaan yang berbeda lokasi melakukan M\&A maka hampir dipastilkan bahwa kedua perusahaan tersebut mempunyai perbedaan dalam perilaku dan budaya organisasi.

Sebagai contoh, perusahaan yang berlokasi di negara yang masyarakatnya cenderung kolektif mengakuisisi perusahaan yang masyarakatnya individualis seperti perusahaan Jepang mengakuisisi perusahaan Amerika, diperkirakan akan mempunyai gaya kepemimpinan dan proses pengambilan keputusan yang berbeda (Lincoln, 1989; DeFrank, et.al., 1985). Perbedaan sistem 
nilai kedua negara inilah yang menjadi sumber masalah dalam M\&A lintas negara (lihat misalnya: Veri, Lubatkin, and Calori, 1996; Schweiger, Csiszar, and Napier, 1993; Veiga et al., 2000).

Sementara itu jenis perkawinan yang paling ideal adalah perkawinan kolaboratif. Jenis perkawinan ini sering dikatakan sebagai M\&A yang sesungguhnya. Akan tetapi dalam praktek, banyak perusahaan yang pada mulanya bertekad melakukan perkawinan kolaboratif, dalam perjalanannya sering menyimpang mengarah ke perkawinan tradisional. Penyimpangan ini terjadi salah satunya karena tingkat kepercayaan terhadap pihak lain relatif rendah (Marks and Mirvis, 1998) akibatnya masing-masing pihak cenderung mempertahankan mind-setnya dan meng-klaim bahwa pihaknya lebih pantas mengarahkan/mengatur perusahaan baru. Dari sinilah awal terjadinya pergeseran dari perkawinan kolaboratif ke perkawinan tradisional, dan kecenderungan seperti ini tampaknya tidak bisa dihindarkan. Bukan hanya itu, perkawinan terbuka pun bisa berubah ke arah perkawinan tradisional selama perasaan superioritas masih menyelimuti masing-masing pihak yang terlibat dalam perkawinan.

\section{PERKAWINAN TRADISIONAL DAN IMPLIKASINYA} TERHADAP MANUSIA DAN BUDAYA

Mengingat bahwa jenis perkawinan yang paling bermasalah adalah perkawinan tradisional di mana tingkat perceraiannya relatif tinggi (mencapai lebih dari 50\% dan lebih dari 30\% diantaranya karena persoalan manusia dan budaya) maka jenis perkawinan inilah yang patut mendapat banyak perhatian. Berdasarkan asumsi ini maka pada bagian ini akan dijelaskan (1) beberapa implikasi yang mungkin ditimbulkan perkawinan tradisional terhadap manusia dan budaya, (2) tindakan-tindakan pencegahan yang perlu dilakukan dan (3) bagaimana meng-integrasikan variabel manusia dan budaya agar M\&A bisa bertahan lama dan mencapai tujuannya.

\section{Beberapa Persoalan Umum dalam Perkawinan Tradisional}

Masuknya investor asing ke PDAM Jaya ternyata tidak diikuti oleh kinerja yang menggembirakan. Yang terjadi justru sebaliknya, resistensi karyawan terhada kehadiran investor tersebut tampak begitu tinggi1. Contoh ini menunjukkan betapa rentannya masalah penggabungan usaha khususnya jika penggabungan tersebut terjadi dalam bentuk perkawinan tradisional. Secara umum, gangguan M\&A yang berasal dari faktor manusia dan budaya tidak semata-mata datang saat M\&A diimplementasikan dan pada periode-periode sesudahnya (seperti pada kasus PDAM Jaya) melainkan juga jauh sebelum

\footnotetext{
${ }^{1}$ Beberapa waktu yang lalu media massa secara luas memberitakan kasus demonstrasi berkepenjangan yang dilakukan oleh karyawan PDAM Jaya berkaitan dengan masuknya pemodal asing kedalam tubuh PDAM Jaya. Pada intinya demonstrasi ini merupakan penolakan terhadap kehadiran pemodal asing meski Pemda telah menyetujui masuknya investor tersebut.
} 
M\&A disepakati dan sah secara hukum seperti dijelaskan pada uraian berikut ini.

Masalah M\&A sebelum Bergabungnya Dua Perusahaan. Sebelum M\&A terealisir yakni saat proses negosiasi berlangsung², para eksekutif (khususnya yang tidak terlibat dalam pengambilan keputusan) dan karyawan dari perusahaan yang akan digabung biasanya menghadapi apa yang disebut merger syndrome masa-masa tidak menentu, khawatir, dan takut akan ketidak pastian nasib mereka dimasa datang (Ashford, 1988; Mark and Mivis, 1997; Schweiger, Ivancecich and Power, 1987). Syndrome ini terjadi karena dalam proses negosiasi M\&A, umumnya fokus pembicaraan hanya seputar aspek legal dan finansial, misalnya berapa nilai perusahaan yang akan digabung, bagaimana cara pembayarannya termasuk waktu dan struktur pembayaran, dan sejauh mana penggabungan tersebut tidak melanggar hukum yang berlaku. Itulah sebabnya dalam proses pengambilan keputusan ini para akuntan dan analis keuangan seringkali melakukan due dilligence - meneliti dengan cermat neraca perusahaan, mempelajari dengan baik proyeksi permintaan dan kapasitas perusahaan, dan melakukan tindakantindakan/analisis kuantitatif lain yang dianggap perlu untuk menegaskan bahwa pengggabungan dua perusahaan tersebut merupakan tindakan yang rasional dan diharapkan memperoleh keuntungan sebagaimana mestinya (Grossman, 1999; Legare, 1998).

Sementara itu, hal-hal yang berkaitan dengan aspek manusia - nasib karyawan, hampir tidak pernah dibicarakan. Kalau toh agenda pembicaraan menyangkut hal tersebut, yang mereka bicarakan sebatas berapa banyak karyawan yang harus diPHK agar perusahaan efisien secara finansial, dan berapa karyawan yang harus dialih tugaskan karena adanya perampingan struktur organisasi. Selebihnya, apakah dikemudian hari karyawan lama tetap dipertahankan, apakah akan terjadi konflik kepentingan antar karyawan dari perusahaan yang bergabung, apakah mereka bisa secara cepat beradaptasi dengan lingkungan baru, dan apakah value system dan budaya kedua perusahaan kompatibel sering luput dari agenda pembahasan. Oleh sebab itu, lepas dari bagaimana pengambil alihan tersebut dilaksanakan yakni apakah bersifat hostile atau friendly, apakah perusahaan yang akan diambil alih sebelumnya mengalami financial distress atau tidak, apakah lingkupnya domestik atau internasional atau apakah M\&A terjadi antara kegiatan usaha sejenis atau tidak, usulan tentang M\&A seringkali ditanggapi karyawan dengan sikap negatif sampai terbukti bahwa kepentingan mereka tidak terganggu. Jadi, semakin lama proses negosiasi dan semakin tidak menentu keputusan M\&A, karyawan akan semakin resah dan sikap karyawan terhadap M\&A semakin negatif (Feldman, 1995, Schweiger, Csiszar and Napier, 1993).

\footnotetext{
2 proses pengambilan keputusan M\&A biasanya hanya melibatkan beberapa orang saja, utamanya: Pimpinan puncak kedua perusahaan yang akan bergabung, beberapa direktur, investmen bankers, penasehat hukum, dan orang ketiga atau perantara yang dekat dengan kedua perusahaan yang akan bergabung (Legare, 1998)
} 
Pandangan dan sikap negatif inilah yang menjadi pemicu dan merupakan tanda-tanda awal karyawan mengalami stress di tempat kerja (Cooper and Cartwright, 1994; George and Jones, 1999: 303; Marks and Mivis, 1997, 1998; Veri, Lubatkin and Calori, 1996). Secara definitif yang dimaksud dengan stress di tempat kerja (occupational stress) adalah persepsi seseorang terhadap kondisi dinamis di tempat kerja ketika mereka menghadapi kesempatan, ancaman atau tuntutan dalam pekerjaan yang hasilnya dianggap sangat menentukan tetapi tidak pasti sehingga orang tersebut merasa tidak mampu mengatasinya secara efektif (lihat misalnya: George and Jones, 1999: 291; Robbins, 1996: 611).

Berdasarkan definisi ini maka bisa dikatakan bahwa M\&A merupakan sumber terjadinya stress sebab M\&A merupakan ancaman bagi karyawan meski ancaman tersebut masih berupa symptom, belum riil. Artinya ketika karyawan mendengar rumor bahwa perusahaan tempatnya bekerja akan dimerger atau diakuisisi, mereka sudah merasa trauma dan takut akan nasibnya dimasa datang, takut kehilangan teman kerja, takut akan menghadapi masalah keluarga dan takut akan kehilangan identitas dirinya. Ketakutan ini mungkin disebabkan karena pengalaman masa lalu khususnya bagi karyawan yang pernah mengalami nasib serupa atau dari cerita-cerita negatif tentang M\&A yang berasal dari tetangga, teman atau famili.

Definisi di atas juga menyiratkan bahwa stress pada dasarnya lebih merupakan persepsi subyektif karyawan ketimbang realitas obyektif. Oleh karenanya meningkat tidaknya stress bervariasi antara satu karyawan dengan karyawan lain dan bergantung pada dua hal yaitu: (1) sistem nilai yang mereka anut (Hofstede, 1997) dan (2) kepribadian masing-masing karyawan (George and Jones: 293). Pertama, seorang karyawan yang secara kultural mempunyai tingkat penghindaran yang tinggi terhadap ketidak menentuan - high uncertainty avoidance (Hofstede, 1980, 1997) dan menjunjung nilai-nilai keamanan keluarga (family security) sebagai pandangan hidupnya (lihat A. Sobirin, 1997) kemungkinan akan mengalami stress yang lebih tinggi ketimbang kelompok lain. Sebagaimana dijelaskan oleh Hofstede, uncertainty avoidance adalah suatu sistem nilai dalam masyarakat di mana sekelompok orang (masyarakat) menjunjung tinggi nilai-nilai kepastian oleh karenanya ketidak pastian (uncertainty) akan dihindarkan. Jadi, usulan tentang penggabungan atau pengambil alihan perusahaan yang pada dasarnya menjadikan seseorang merasa tidak pasti masa depannya dan kehidupan keluarganya terganggu, merupakan sesuatu yang menakutkan bagi sebagian orang.

Kedua, karakter seseorang yang tercermin dalam personality (kepribadiannya) juga akan berpengaruh terhadap tinggi rendahnya stress ketika issue tentang M\&A mulai merebak. Sebagaimana telah disebutkan di atas, stress pada dasarnya bukan merupakan persepsi kelompok, melainkan persepsi individual. Oleh karenanya apakah usulan M\&A akan meningkatkan stress atau tidak bergantung pada kepribadian mereka. Seorang karyawan dengan kepribadian Type $A$ - yakni sifat seseorang yang cenderung tidak sabar, tidak bisa kerja sama dengan orang lain, mudah bergejolak, sangat kompetitif, dan ingin mencapai sesuatu dengan cepat; diperkirakan akan mengalami stress lebih tinggi 
ketimbang karyawan dengan Type $B$ - kepribadian yang cenderung rileks dan mudah menyesuaikan diri. Hal yang sama juga akan dialami oleh karyawan dengan internal locus of control - kepribadian yang mengarah pada pemahaman bahwa kemampuan, usaha, tindakan yang dilakukannya dapat mempengaruhi nasibnya dibandingkan karyawan dengan external locus of control - yakni kepribadian yang menganggap bahwa nasibnya ditentukan oleh faktor eksternal (orang lain) dan apa yang mereka lakukan sangat kecil pengaruhnya terhadap nasib mereka, (George and Jones, 48-49; 293-294).

Penjelasan di atas sekali lagi menegaskan bahwa sejak awal yakni sejak M\&A masih berupa usulan, masih berupa rumor dan belum riil, M\&A sudah memunculkan persoalan-persoalan tersendiri. Paling tidak, M\&A dianggap menjadi pemicu timbulnya stress dikalangan karyawan. Jika kondisi ini tidak diantisipasi sejak dini bisa menyebabkan implikasi-implikasi lebih lanjut seperti adanya gangguan psikologis, fisiologis dan behavioral karyawan ${ }^{3}$.

Masalah M\&A Selama dan Sesudah Penggabungan Dua Perusahaan. Segera setelah keputusan M\&A disepakati, tindakan-tindakan nyata untuk merealisasi tujuan M\&A mulai dilakukan. Dengan diimplementasikannya M\&A bukan berarti persoalan-persoalan manusia dan budaya berakhir. Justru sebaliknya, ada kemungkinan M\&A menghadapi persoalan-persoalan lebih besar seperti berlanjutnya stress dan bahkan burnout - kelelahan fisik dan mental berkepanjangan di kalangan karyawan dan para eksekutif. Jika stress yang terjadi sebelum implementasi lebih berupa symptom, maka setelah implementasi M\&A, karyawan mengalami stress karena secara riil menghadapi perbedaan-perbedaan nyata yang tidak pernah dialami sebelumnya seperti perbedaan gaya kepemimpinan, budaya organisasi atau orientasi perusahaan. Semua perbedaan ini akhirnya mengarah pada terjadinya ketidak cocokan organisasi (organizational misfit) (Marks and Mirvis, 1997, 1998; Legare, 1998). Oleh Very, Lubatkin and Calori (1996) stress semacam ini disebut sebagai acculturative stress.

Acculturative stress sebetulnya tidak selalu berdampak negatif menurunkan semangat kerja karyawan dan kinerja perusahaan (Schweiger, Ivancevich and Power, 1987) tetapi juga bisa berdampak positif. Artinya acculturative stress bisa meningkatkan kinerja perusahaan baru (setelah merger/akuisisi). Semua dampak ini, baik positif maupun negatif, sangat bergantung pada bagaimana reaksi karyawan terhadap perubahan-perubahan organisasi. Reaksi karyawan terhadap perubahan budaya sebagai akibat adanya perubahan organisasi, seperti dikatakan Harris and Ogbonna (1998), bisa bervariasi mulai dari reaksi yang sangat positif, active acceptance menerima perubahan apa adanya sampai pada reaksi yang paling negatif, active rejective - serta merta menolak perubahan budaya (lihat gambar 1).

\footnotetext{
${ }^{3}$ uraian detail tentang implikasi stress terhadap gangguan psikologis, fisiologis dan
} behavioral selengkapnya dapat dilihat pada George and Jones, 1999, pp. 294-297 
Gambar 1: Bentuk-bentuk reaksi perubahan dan aspek-aspeknya

\begin{tabular}{|c|c|c|}
\hline & $\begin{array}{l}\text { Bentuk tanggapan } \\
\text { karyawan }\end{array}$ & Aspek-aspek perubahan budaya \\
\hline & Active Acceptance & Karyawan menerima apa adanya perubahan budaya \\
\hline & Selective reinvention & $\begin{array}{l}\text { - Secara selektif, karyawan mencoba mendaur ulang beberapa } \\
\text { elemen budaya lama (seolah-olah) menjadi budaya baru } \\
\text { meski esensinya tidak ada perubahan, beberapa artefak } \\
\text { misalnya diberi label baru. }\end{array}$ \\
\hline 3. & Reinvention & $\begin{array}{l}\text { - Secara umum karyawan enggan melakukan perubahan. } \\
\text { Budaya lama, bukan hanya beberapa elemen, didaur ulang } \\
\text { seolah-olah membentuk budaya baru. }\end{array}$ \\
\hline 4. & General acceptance & $\begin{array}{l}\text { - Secara umum karyawan mau menerima perubahan meski } \\
\text { tidak sepenuhnya seperti pada active acceptance. Ada } \\
\text { bebarapa perubahan yang ditolak dengan asumsi budaya } \\
\text { lama masih ada yang cocok. }\end{array}$ \\
\hline 5. & Dissonance & $\begin{array}{l}\text { Karyawan mengalami keraguan antara menerima dan menolak } \\
\text { perubahan. Hal ini ditandai dengan prilaku karyawan yang tidak } \\
\text { konsisten. }\end{array}$ \\
\hline 6. & General rejection & $\begin{array}{l}\text { - Secara umum karyawan menolak perubahan meski kemung- } \\
\text { kinan perubahan masih diterima dengan alasan budaya lama } \\
\text { tidak lagi kondusif dengan lingkungan baru. }\end{array}$ \\
\hline 7. & Reinterpretation & $\begin{array}{l}\text { - Secara umum karyawan mencoba menginterpretasikan per- } \\
\text { ubahan dan menyesuaikan diri, secara behavioral, dengan } \\
\text { perubahan tersebut. }\end{array}$ \\
\hline 8. & $\begin{array}{l}\text { Selective } \\
\text { reinterpretation }\end{array}$ & $\begin{array}{l}\text { - Karyawan menginterpretasikan kembali beberapa komponen } \\
\text { budaya dan nenolak sebagian komponen yang lain. }\end{array}$ \\
\hline & Active rejection & Karyawan serta merta menolak perubahan budaya \\
\hline
\end{tabular}

Sumber : Achmad Sobirin, 2000, hal. 40

Dalam hal ini, jika karyawan menganggap bahwa budaya lama sudah tidak lagi kondusif untuk menjalankan kegiatan perusahaan maka M\&A yang menawarkan budaya baru akan ditanggapi karyawan dengan antusiasme sebagai upaya perbaikan budaya yang secara berturut-turut diharapkan bisa memperbaiki perubahan lingkungan kerja. Karyawan akan menganggap bahwa M\&A bisa menjadi ajang untuk memperbaiki kinerja perusahaan. Sebaliknya jika karyawan menganggap bahwa budaya lama sudah menjadi bagian dari hidup mereka yang tidak perlu dirubah maka M\&A yang menawarkan budaya baru akan ditanggapi secara negatif. Kecenderungannya karyawan akan menolak perubahan budaya tersebut yang berarti pula menolak $M \& A$.

Jika ditelusuri lebih jauh, semua permasalahan ini sesungguhnya bermula dari dua hal yakni: (1) implementasi M\&A identik dengan perubahan yang dampaknya sering kali tidak bisa diprediksi dan (2) dalam praktek, yang 
mengimplementasikan M\&A adalah orang-orang yang sejak awal tidak terlibat dalam pengambilan keputusan. Pertama, implementasi M\&A umumnya dimulai dengan mengadakan perubahan-perubahan organisasi baik yang mendasar maupun operasional. Secara natural ada tiga jenis perubahan yang biasa terjadi dalam M\&A (Schweiger, Csiszar and Napier, 1993) yakni menutup satu atau beberapa departemen tertentu, mengkombinasikan dua departemen menjadi satu, dan menciptakan interrelasi dua unit atau lebih yang sebelumnya tidak punya hubungan.

Disamping perubahan-perubahan di atas, kadang-kadang perubahan yang lebih mendasar seperti merubah strategi, bahkan merubah misi dan visi sering tidak bisa dihindarkan. Perubahan-perubahan ini sering membawa implikasi terhadap perubahan budaya organisasi, praktik manajemen sumber daya manusia, prosedur operasional, sistem manajemen dan identitas organisasi. Padahal seperti telah kita ketahui sebelumnya, masing-masing perusahaan, sebelum bergabung, mempunyai mind-set atau mental programming yang berbeda dan cenderung dipertahankan (Hofstede, 1997; Marks and Mivis, 1998)). Oleh karenanya per-ubahan organisasi yang identik dengan perubahan mind-set (Bate, 1994) merupakan permasalahan tersendiri dalam M\&A.

Sebagai contoh, segera setelah Hewlett Packard (HP) mengakuisisi Apollo Computer (AC), HP melakukan downsizing, kata lain dari pemutusan hubungan kerja (PHK). Akibatnya, dari 500 karyawan kantor pusat Apollo (yang sekarang sudah menjadi salah satu divisi HP), 150 orang diantaranya oleh manajemen HP dianggap menempati posisi yang sudah tidak diperlukan lagi dalam struktur organisasi HP. Oleh karenanya ke 150 orang tersebut perlu direlokasi jika memungkinkan, tetapi jika tidak, mereka terpaksa harus menjalani pensiun dini dengan pesangon minimal 3 bulan gaji. Sekali lagi, relokasi ini dilakukan sebagai konsekuensi dari perubahan struktur organisasi Apollo. Perubahan-perubahan lain juga dilakukan HP yakni merubah sistem informasi, sistem penggajian dan sistem perencanaan jangka panjangnya (lihat Legare, 1998). Akibat dari perubahan-perubahan tersebut, krisis organisasi tidak terhindarkan dan banyak karyawan yang mengalami stress berkepanjangan. Bahkan Thomas A. Vanderslice dan Richard P. Bond - masing-masing sebagai CEO dan CFO Apollo terpaksa mengundurkan diri padahal Vanderslice sebelumnya mengatakan bahwa merger antara HP dan AC merupakan win-win solution.

Kedua, setelah M\&A disepakati, yang mengimplementasikan kesepakatan tersebut bukanlah pimpinan puncak dan jajarannya yang membuat kesepakatan M\&A melainkan mereka yang sejak semula tidak terlibat dalam pengambilan keputusan dan sebelumnya bahkan mengalami merger syndrome. Oleh karenanya sering terjadi sinergi dan keuntungan yang diharapkan dari M\&A tidak pernah terealisir. Sebab utamanya (1) adanya reisitensi dan penolakan para eksekutif dan karyawan untuk berpartisipasi dalam implementasi M\&A (2) karena sejak semula tidak terlibat dalam kesepakatan awal, mereka tidak memahami karakter masing-masing perusahaan yang dimerger/diakuisisi, akibatnya seperti digambarkan Mirvis and Sales (1990), mereka memahami M\&A seperti orang buta mencoba mengenali gajah, yakni memahami M\&A 
secara fragmented (sepotong-sepotong) sesuai dengan persepsi mereka, dan (3) tidak adanya pemahaman dan mind-set yang sama, berakibat pula terjadinya salah paham dan konflik antar kelompok karyawan dari perusahaan yang bergabung (lihat juga Marks and Mirvis, 1998) serta terjadinya benturanbenturan budaya (cultural clash).

\section{Tindakan Pencegahan}

Untuk menghindarkan atau paling tidak meminimalisir persoalanpersoalan tersebut di atas maka sejak awal perlu ada tindakan pencegahan yang patut dilakukan, diantaranya:

1. Sebelum kesepakatan M\&A ditandatangani, pihak yang berinisiatif melakukan M\&A perlu melakukan due diligence yang tidak terbatas pada aspek legal dan finansial saja tetapi meluas sampai pada aspek budaya. Atau dengan kata lain audit budaya perlu dilakukan sebelum kesepakatan M\&A ditandatangani (dalam kaitannya dengan audit budaya lihat misalnya, Fletcher and Jones, 1992; Thusman and O'Reilly III, 1997). Tujuannya adalah untuk memahami sejauh mana perbedaan budaya (cultural gap) diantara kedua belah pihak, jika ada, bisa mengganggu kelancaran M\&A (Weber, 1996).

Untuk mengetahui ada tidaknya gap, dengan demikian audit budaya harus dimulai dari diri sendiri. Artinya, perusahaan yang berinisiatif melakukan M\&A harus terlebih dahulu memahami budaya organisasinya budaya seperti apa yang berkembang di perusahaannya. Sebab, seperti dikatakan oleh Grossman (1999), sering terjadi para eksekutif justru berbeda pandangan dengan staffnya tentang budaya perusahaannya. Misalnya, para eksekutif mengklaim bahwa perusahaan yang dikelolanya lebih people oriented, sementara para karyawan mengatakannya lain. Oleh karenanya perbedaan pandangan ini harus diluruskan terlebih dahulu sebelum audit budaya terhadap target perusahaan yang akan dimerger/diakuisisi dilaksanakan. Hasil audit ini kemudian digunakan sebagai dasar untuk memutuskan apakah nantinya implementasi M\&A memerlukan perubahan budaya atau tidak.

2. Selain audit budaya, karyawan juga harus dibekali dengan persiapan psikologis tentang kemungkinan-kemungkinan yang bakal terjadi sesudah M\&A sah secara hukum (Mark and Mirvis, 1998). Bekal tersebut tidak hanya diberikan kepada karyawan dari perusahaan yang akan dimerger/akuisisi tetapi juga kepada karyawan dari perusahaan yang memimpin merger. Tujuannya agar karyawan dan para manajer kedua belah pihak menyadari bahwa tidak ada tujuan lain dari penggabungan usaha ini kecuali untuk memperbaiki kinerja kedua belah pihak. Dalam hal ini pihak pembeli dituntut untuk lebih sabar dan sensitif dalam mengimplementasikan M\&A. Sebaliknya, pihak penjual juga harus menyadari bahwa mereka ada dipihak yang lemah sehingga secara emosional harus mau menerima pihak lain (perusahaan pembeli) jika pihak lain tersebut terpaksa harus mengontrolnya. 
Untuk membekali karyawan dan para manajer dengan persiapan psikologis, ada beberapa cara yang bisa ditempuh. Diantaranya dengan menyelenggarakan seminar tentang implikasi M\&A terhadap masa depan perusahaan dan sekaligus terhadap karyawan. Tentunya seminar ini harus melibatkan karyawan kedua belah pihak agar terjadi dialog diantara mereka. Dalam seminar ini perlu didistribusikan pula booklet, sebagai guidance, yang menjelaskan mind-set kedua belah pihak, aturan main bagi kedua belah pihak, prospek perusahaan setelah M\&A, konsekuensinya tehadap manusia dan budaya, dan cara-cara mengatasi dampak negatif dari M\&A, jika ada, seperti stress dan burn-out atau perbedaan kultural. Cara lain yang lebih dinamis misalnya dengan mengundang para veteran yang pernah mengalami atau terlibat dalam M\&A untuk share pengalaman. Bagi karyawan dan eksekutif yang sedang khawatir dan takut akan dampak negatif M\&A, share pengalaman dari pendahulunya sangat berguna untuk meredam kekhawatiran tersebut dan untuk menegaskan bahwa M\&A tidak semenakutkan seperti yang dibayangkan.

3. Mengintensifkan peran Manajer Sumber Daya Manusia (SDM). Dalam kaitannya dengan audit budaya maupun pemberian bekal psikologis bagi karyawan, tampaknya keterlibatan manajer SDM merupakan suatu keharusan. Merekalah yang harus berperan aktif dalam mengidentifikasikan beberapa masalah yang mungkin timbul akibat M\&A. Mereka juga yang harus mengkomunikasikan dan mensosialisasikan maksud diputuskannya M\&A, visi kedepan perusahaan, strategi dan kebijakan yang akan ditempuh dan peran masing-masing pihak setelah M\&A sah secara hukum.

Keterlibatan manajer SDM dengan demikian merupakan komitmen awal dari jajaran eksekutif puncak untuk meyakinkan semua pihak bahwa kepentingan-kepentingan mereka, semaksimal mungkin, akan diakomodasi manakala M\&A sah secara hukum. Dalam penelitiannya Weber (1996) mengatakan bahwa komitmen pimpinan puncak mempunyai korelasi positif dengan efektifitas proses integrasi dan kinerja perusahaan gabungan. Semakin pimpinan puncak memiliki komitmen yang tinggi semakin efektif pula proses integrasi dan semakin baik kinerja perusahaan, demikian sebaliknya. Tanpa komitmen, dengan demikian, bukan tidak mungkin berbagai sikap negatif khususnya yang datang dari karyawan dari perusahaan yang akan dimerger/akuisisi bermunculan. Sikap negatif ini tentunya harus dihindarkan jika perusahaan tidak ingin menghadapi berbagai macam kesulitan dikemudian hari.

\section{Mengintegrasikan manusia dan budaya}

Seperti telah disebutkan di atas, masalah yang paling krusial dalam M\&A dan merupakan test case apakah nantinya M\&A bisa berhasil atau tidak adalah mengintegrasikan dua perusahaan yang semula berdiri sendiri kedalam wadah baru yakni perusahaan gabungan, khususnya masalah yang berkaitan dengan aspek manusia dan budaya. Masalah ini muncul karena dalam batasbatas tertentu, implementasi M\&A identik dengan perubahan, sekecil apapun 
perubahan tersebut. Jadi, dampak dari perubahan inilah yang sebetulnya paling ditakutkan karyawan. Oleh karenanya komitmen pimpinan puncak menjadi salah satu determinan penting dalam mengintegrasikan manusia dan budaya.

Selain komitmen pimpinan puncak, ada variabel lain yang turut menentukan berhasil tidaknya proses integrasi. Variabel tersebut adalah: (1) strategi, (2) tingkat kecocokkan budaya dan (3) karakter politik dan tingkat konflik yang berkembang selama integrasi berlangsung (Pablo, 1994). Variabel ini juga ikut menentukan pada level mana integrasi tersebut harus dilakukan. Pertama, berbicara tentang strategi berarti kita harus terlebih dahulu memahami motivasi atau alasan mengapa kedua perusahaan tersebut bergabung dan mengidentifikasi sumber daya yang harus dipertahankan agar penggabungan usaha tersebut mencipatakan sinergi. Sebagai contoh, jika tujuan penggabungan kedua perusahaan hanya sebatas menciptakan sinergi finansial, maka tingkat integrasinya relatif rendah karena interaksi kedua perusahaan tidak begitu penting. Sebaliknya jika tujuannya adalah menciptakan sinergi operasional maka keterlibatan dan interaksi kedua perusahaan sangat penting. Hal ini berarti interaksi karyawan dari kedua belah pihak juga tidak bisa dihindarkan.

Variabel kedua adalah budaya. Dalam konteks organisasi, budaya organisasi merupakan variabel internal yang menggambarkan konfigurasi organisasi secara keseluruhan (Smircich, 1983), mencerminkan identitas diri para anggotanya (Deal and Kennedy, 1982, 1999), menggambarkan upaya organisasi untuk mempertahankan identitas dirinya saat terjadi perubahan (Louis, 1983), mempengaruhi efektifitas organisasi dalam merespon perubahan lingkungan (Schein, 1990) dan mendorong komitmen para pimpinan dan keseluruhan organisasi (Siehl and Martin, 1981).

Dalam konteks M\&A, dengan demikian, bagaimana sebuah organisasi memenej budayanya yakni kuat tidaknya budaya - strong vs. weak culture (Peter and Waterman, 1982), dan variasi budaya dalam sebuah organisasi - mono vs. multikultur (A. Sobirin, 1999) akan berpengaruh terhadap desain dan efektifitas proses integrasi. Organisasi yang memiliki multikultur cenderung memberikan toleransi terhadap perbedaan budaya yang berarti pula keleluasaan untuk mempertahankan nilai-nilai, keyakinan, dan praktek-praktek manajemen bagi perusahaan yang dimerger/akuisisi relatif tinggi. Sebaliknya bagi perusahaan yang memimpin M\&A memiliki budaya yang kuat dan monokultur cenderung menghendaki agar perusahaan yang dimerger/akuisisi menyesuaikan diri dengan budaya perusahaan yang memimpin M\&A. Atau dengan kata lain, level integrasinya rendah bagi perusahaan yang memiliki multikultur dan tinggi bagi perusahaan yang monokultur (Pablo, 1994).

Varibel ketiga adalah karakter politik dan tingkat konflik. Karena kesepakatan M\&A cenderung bersifat implisit, tidak eksplisit, maka saat proses integrasi berlangsung yakni saat kedua belah pihak berupaya menyesuaikan diri dengan perusahaan baru biasanya banyak ditemukan hal-hal yang ambigius yang bersifat interpretatif. Oleh karenanya, nuansa politik yang diikuti oleh timbulnya konflik kepentingan diantara kedua perusahaan seringkali tidak 
bisa dihindarkan. Pada saat seperti ini perusahaan yang memimpin M\&A, dengan powernya, berusaha menguasai perusahaan lain, baik dalam hal sumber daya maupun penetapan tujuan. Sebaliknya, perusahaan yang dimergerlakuisisi meski pada posisi yang lebih lemah juga berusaha melakukan hal yang sama.

Desain dan proses integrasi M\&A dengan demikian sangat dipengaruhi dua variabel penting yakni power (kekuasaan), dan kemampuan perusahaan untuk menggunakan kekuasaan tersebut. Dari perspektif perusahaan yang memimpin M\&A, perlu tidaknya menggunakan power bergantung pada tingkat kompatibelitas kedua perusahaan yang bergabung. Jika tingkat kompetibelitas tersebut tinggi (yang berarti masing-masing pihak berusaha maksimal memperebutkan sumber daya dan tujuan perusahaan yang baru), bisa diduga bahwa perusahaan yang memimpin M\&A menganggap perlu untuk menggunakan powernya dalam rangka mencapai tujuan M\&A. Demikian sebaliknya, jika tingkat kompatibelitasnya rendah seperti terjadi pada penggabungan usaha tidak sejenis, maka ada kecenderungan rendahnya penggunaan kekuasaan dalam mencapai tujuan M\&A.

Namun harus dipahami pula bahwa digunakan tidaknya power yang dimiliki perusahaan yang memimpin M\&A akan bergantung pula pada kemampuan perusahaan tersebut memanfaatkan power yang ada. Jika perusahaan yang memimpin M\&A jauh lebih besar dibanding perusahaan yang dimerger/akuisisi maka bisa diduga bahwa perusahaan tersebut mempunyai kemampuan untuk menggunakan powernya sebab perbedaan besaran ini pada akhirnya akan menciptakan power differensial diantara kedua perusahaan. Semakin besar perbedaannya, perusahaan yang lebih besar semakin mendominasi perusahaan yang lebih kecil dan sebaliknya rendahnya power differensial semakin rendah pula dominasi terhadap perusahaan lain. Power dan kapabilitas untuk memggunakannya dengan demikian menjadi elemen kunci yang menentukan cepat atau lambat dan mulus tidaknya proses integrasi, dan menentukan level integrasinya.

\section{PENUTUP}

Dengan menggunakan metafora sebuah perkawinan, masalah merger dan akuisisi (M\&A) didiskusikan dalam tulisan ini dengan menempatkan manusia dan budaya menjadi tema sentralnya. Meski demikian, tulisan ini tidak mengatakan bahwa keberhasilan M\&A semata-mata ditentukan oleh kedua variabel tersebut. Yang ingin lebih mempertegas dalam tulisan ini adalah manusia dan budaya bisa menjadi variabel penghambat keberhasilan $\mathrm{M} \& \mathrm{~A}$ mengingat pengalaman sebelumnya menunjukkan bahwa hampir 50\% tingkat kegagalan M\&A karena kedua varibel ini. Oleh karena itu tidak berlebihan jika tulisan ini menyarankan agar kedua variabel di atas perlu mendapatkan perhatian yang lebih besar ketika para pengambil keputusan berketetapan memutuskan M\&A mengingat sebelum, selama dan sesudah M\&A berlangsung masalah manusia dan budaya selalu mengiringinya. 


\section{DAFTAR PUSTAKA}

Achmad Sobirin (1997), Organizational culture: Konsep, kontroversi, dan manfaatnya untuk pengembangan organisasi, Jurnal Akuntansi dan Auditing Indonesia, Vol 1 no 2. Hal. 152-173

Achmad Sobirin (1999), Memahami arti dan makna budaya organisasi, Jurnal Sinergi, Magister Manajemen UII, Vol. 2 no. 2, halaman 189-215

Achmad Sobirin (2000), Privatisasi: Implikasinya terhadap perubahan prilaku karyawan dan budaya organisasi, Jurnal Siasat Bisnis, no. 5 vol. 1, halaman 25-48.

Abdul Moin, 1999, Mencermati trend 'Mega-Merger': Studi kasus tentang "merger -mania di Amerika, Harian Republika, 7/10/1999

Ashford, S.J., 1988, Individual strategies for coping with stress during organizational transitions, Journal of Applied Behavioral Science, vol. 24 (1), pp. 19-36

Ashforth, B.E. and F.Mael (1989), Social identity theory and the organization, Academy of management review, 14, pp. 20-39

Bate, P. (1994), Strategies for Cultural Change ${ }_{1}$ Oxford: Butterworth Heinemann

Cartwright, S. and Cooper, C.L., 1993a, The role of culture compatibility in successful organizational marriage, Journal of Management Executive, May; $7(2)$, pp. 57-70.

Cartwright, S. and Cooper, C.L., 1993b, Of mergers, marriage and divorce: The issues of staff retention, Journal of Managerial Psychology. 8(6), pp. 7-10.

Cartwright, S. and Cooper, C.L., 1993c, The psychological impact of merger and acquisition on the individual: A study of building society managers, Human Relation, March, pp. 327-331

Cartwright, S. and Cooper, C.L., 1995, Organizational marriage:"Hard" versus "soft" issues? Personnel Review. 24(3), pp. 32-42

Chatterjee, S., M.Lubatkin, D.M.Schweiger and Y.Weber, 1992, Cultural differences and shareholder value in related mergers: Linking equity and human capital, Strategic management journal, 13, pp. 319-334

Cooper, C.L. and S. Cartwright, 1994, Healthy mind - Healthy organization: A proactive approach to occupational stress, Human Reations, April, pp. 455-471

Davy, J.A., A.Kinicki, J.Kilroy and C.Scheck, 1988, After the merger: Dealing with people's uncertainty, Training and development journal, Nov., pp.57-61

Davy, J.A., A.Kinicki, C.Scheck and J.Kilroy,1989, Acquisition make employees worry, The personnel administrator, August, pp. 84-89

Deal, T.E and A.A. Kennedy (1982), Corporate culture: The rites and rituals of corporate life, Reading Mass.: Addison Wesley Publishing

Deal, T.E and A.A. Kennedy (1998), New corporate culture, Cambridge, Mass.: Perseus publishing 
DeFrank, R.S., M.T. Matteson, D.M. Schweiger and J.M. Ivancevich, 1985, The impact of culture on the management practices of American and Japenese CEOs, Organization Dynamics, Spring, pp. 62-76

Elsass, P.M. and J.F. Veiga, 1994, Acculturation in acquired organizations: A force-field perspective, Human Reations, April, pp. 431-454

Feldman, M.L., 1995, Disaster prevention plans after a merger, Merger and Acquisition, July/August, 30, pp. 31-36

Fletcher, B. and F. Jones (1992), Measuring organizational culture: The cultural audit, Managerial auditing journal, 7(6), pp. 30-36

George, M.J. and G.R. Jones (1999), Understanding and managing organizational behavior, $2^{\text {nd }}$ edition, Reading, Mass: Addison Wesley Pub. Co. Inc.

Grossman, R.J., 1999, Irreconcilable differences, HRMagazine, April, 44, pp. $42-48$

Harris, L.C, and E. Ogbonna (1998), Employee Responses to Cultural change Efforts, Human Resource Management Journal, Vol. 8 No. 2, pp. 78-92.

Hofstede, G. (1980), Cultural consequences: International difference in work related values, Beverly Hill, CA: Sage Publication

Hofstede, G., 1997, Cultures and Organizations: Sofware of the Mind ${ }_{1}$ New York: McGraw Hill

Hutchison, G.S. (ed.), 1968, The business of acquitions and mergers, New York: President Publishing House Inc.

Ivancevich, J.M., Schweiger, D.M. and Power, F.R., 1987, Strategies for managing human resources during merger and acquisitions, Human Resource Planning, 12, pp. 19-35

Kotter, J.P. and J.L. Heskett (1992), Corporate Culture and Performance ${ }_{1}$ New York: The Free Press

Legare, T.L., 1998, The human side of mergers and acquisitions, Human Resource Planning, 21, pp. 32-41

Lincoln, J.R. (1989), Employee work attitude and management practice in the U.S. and Japan: Evidence from large comparative survey, California Management Review, vol. 32, no. 1, pp. 89-106

Louis, M.R. (1980), Surprise and sense making: What newcomers experience in entering unfamiliar organizational settings, Administrative science quarterly, 25, pp. 226-251

Marks, M.L. and Mirvis, P.H., 1997, Revisiting the merger syndrome: Dealing with stress, Merger and Acquisition, May/June, 31, pp. 21-27

Marks, M.L. and Mirvis, P.H., 1998, How mind-set clashes get merger partners off to a bad start, Merger and Acquisition, Sept/Oct, 33, pp. 28-33

Milman, C.D., 1999, Merger and acquisition activity in China: 1985-1996, Multinational business review, pp. 106-110

Mivis, P.H. and M.L. Marks, 1992, The human side of merger planning: Assessing and analyzing "Fit". Human Resource Planning, Vol. 15, no. 3,

Mirvis, P.H. and Sales A.L., 1990, Feeling the elephant: Culture consequnces of a corporate acquisition and buy-back, in Ben Schneider (ed.), Organizational Climate and Culture ${ }_{\perp}$ San Francisco: Jossey Bass Publisher. pp. 345-382 
Nahavandi, A. and A.R.Malekzadeh (1988), Acculturation in mergers and acquisitions, Academy of management review, 13, 79-90

Napier, N.K., 1989, Merger and acquisition, human resource issues and outcomes: A review and suggested typology, Journal of Management studies, May, vol. 26 (3), pp. 271-289.

Napier, N.K., G. Simmons, and K. Straton, 1989, Communication during a merger: The experience of two banks, Human resource planning, vol. 12 (2), pp. 105-122.

Pablo, A.L., 1994, Determinants of acquisition level: Decision making perspective, Academy of management journal, August, pp. 803-836

Peters, T.J. and R.H. Waterman, Jr. (1982), In Search of Excellence, New York: Harper and Row

Robbins, S P. (1996), Organizational behavior: Concept, controversies and applications, $6^{\text {th }}$ edition, Englewood Cliffs, NJ: Prentice Hall Inc.

Salgo, M.N., 1968, The human aspect of acquisition, in G.S. Hutchison (ed.), The business of acquitions and mergers, New York: President Publishing House Inc. pp.323-331.

Schein, E.H. (1990), Organizational Culture, American Psychologist ${ }_{1}$ February, pp. $109-119$

Schneider, S. and J. Barsoux (1997), Managing Across Culture, Prentice Hall Inc.

Schweiger, D.L and Ivancevich, J.M., 1985, Human resource: The forgotten factor in mergers and acquisition, Personnel Administrator, Nov., vol. 30 (11), pp. 47-61

Schweiger, D.M., Ivancevich, J.M., and Power, F.R., 1987, Executive actions for managing human resources before and after acquisition, Academy of Management Executive, May, Vol. 1(2), pp. 127-138

Schweiger, D.M. and Y. Weber (1989), Strategies for managing human resources during mergers and acquisitions: An empirical study, Human resources planning, 12, pp. 63-86

Schweiger, D.M and A.S. DeNisi (1991), The effects of communication with employees following a merger: A longitudinal field experiment, Academy of manajement journal, 15, pp. 110-135

Schweiger, D.M., E.Csiszar and N.K.Napier (1993), Implementing international mergers and acquisitions, Human resource planning, pp. 53-67

Siehl, C.J. and J.Martin (1981), Measuring organizational culture: Mixing qualitative and quantitative methods. In M.O.Jones et.al (eds) Inside organization: Understanding the human dimension, London: Sage, pp. $79-103$

Smircich, L. (1983), Concept of Culture and Organizational Analysis, Administrative Science Quarterly,28, pp. 339-358.

Thusman, M.L. and C.A. O'Reilly III (1997), Winning through innovation, Boston Ma: Harvard Business School Press.

Veiga, J.F., M.Lubatkin, R.Calori, and P.Very, 2000, Measuring organizational culture clash: A two-nation post-hoc analysis of a cultural compatibility index, Human Relations, April, pp. 539-557 
Very, P., Lubatkin, M., and Calori, R., 1996, A cross-national assessment of acculturative stress in recent European mergers, International Studies of Management and Organization, Spring, 26, pp. 59-86

Weber, Y., 1996, Corporate cultural fit and performance in mergers and acquisitions, Human Relations, 9, pp. 1181-1202 